\title{
Case Report \\ Unsuspected and widespread colon cancer in a young woman
}

\author{
Vitorino Modesto dos Santos ${ }^{1}$, Elaine Pereira \\ Barbiéri de Carvalho2 ${ }^{2}$ Jacira de Azevedo Cortes ${ }^{3}$, \\ Ernesto Misael Cintra 0 sterne ${ }^{2}$.
}

Liver and lung metastasis and local lymph node invasion are reported in a 26-year-old Brazilian woman with an asymptomatic colon cancer. She was admitted complaining of right upper quadrant pain, and the diagnostic procedures revealed an unsuspected adenocarcinoma (stage IV) in the descending colon. This malignancy is more frequent in patients older than 40 years, but it usually follows a more aggressive course in young people. Late detection of colon cancer usually results in worst prognosis (Rev Méd Chile 2008; 136: 221-4).

(Key-words: Colonic neoplasms; Lymphatic metastasis; Neoplasm metastasis)

\section{Cáncer de colon insospechado y diseminado en una mujer joven}

Se presenta un caso en que se demuestran metástasis de un cáncer del colon asintomático en hígado y pulmones, además de invasión local de linfonodos en una mujer brasileña de 26 años de edad. Al ingresar al hospital, la paciente se quejaba de dolor en hipocondrio derecho. Los procedimientos diagnósticos revelaron un adenocarcinoma no sospechado (fase IV) en el colon descendente. Esta malignidad es más frecuente en los pacientes mayores de 40 años, pero suele tener un curso más agresivo en personas jóvenes. La detección tardía del cáncer del colon habitualmente condiciona un peor pronóstico (Rev Méd Chile 2008; 136: 221-4).

(Key words: Colonic neoplasms; Lymphatic metastasis; Neoplasm metastasis)

\begin{abstract}
Recibido el 2 de abril, 2007. Aceptado el 30 de mayo, 2007.
${ }_{1}^{1}$ Professor of the Catholic University Medical Course, and Preceptor of Internal Medicine from the Armed Forces Hospital (HFA), Brasília-DF, Brazil. ${ }^{2}$ Medical Doctor, Department of Internal Medicine from the HFA. ${ }^{3}$ Medical Doctor, Department of Pathology from the HFA
\end{abstract}

$\mathrm{C}_{\mathrm{B}}^{\mathrm{o}}$ olorectal cancer is detected more often in Brazilian people older than 40 years $^{1}$. In spite of the advances in the management and prognosis improvement, it remains among the most frequently diagnosed cancers and is one of the main causes of cancer-related death ${ }^{1-3}$. Moreover, a steady increase in mortality due to colon cancer has been reported ${ }^{4}$.

The most frequent symptoms of colorectal cancer are rectal bleeding, abdominal pain, weight

$\overline{\text { Address to: Prof. Dr. Vitorino Modesto dos Santos. SMPW }}$ Quadra 14 Conjunto 2 Lote 7 Casa A. Setor de Mansões Park Way, 71745-140, Brasília-DF, Brazil. Fax: (0xx55) 61 32330812. E mail: vitorinomodesto@gmail.com loss and constipation or diarrhoea. Early colorectal cancer can be asymptomatic. Prognostic factors include age, per-operative blood transfusions, diameter, depth and pathological type of tumour, local and distant metastases, and the surgical procedure. Worth of note, patients ageing $\leq 30$ years very often present with late stage disease, lymph node metastases and usually they have very poor prognosis ${ }^{1-3}$.

In young people, the main risk factors for colorectal cancer are long lasting inflammatory bowel disease ( $>$ than 8 years), familial adenomatous polyposis and hereditary non-polyposis colorectal cancer syndrome $e^{1,3}$.

In the present case, right hypochondrium pain due to metastases was the initial manifestation of 
an unsuspected descending colon adenocancinoma (stage IV) in a young female. This report aims to highlight the ominous role of cancer diagnosis delay, especially in young people with or without clinical symptoms suggestive of colorectal tumours.

\section{CASE REPORT}

A 26-year-old Brazilian female was admitted complaining of right hypochondrium pain lasting for a week. She came from an Emergency Department where ultrasound and gadolinium MRI studies detected a mass and heterogeneous nodules with contrast enhancement in the liver, and nodules in the lung bases (Figures 1A and 1B). She denied respiratory or gastrointestinal symptoms, tobacco or alcohol consumption, and was treated for genital human papilloma virus (HPV) infection 15 months before. On admission, her general status was good, with body mass index $21 \mathrm{~kg} / \mathrm{m}^{2}$ and temperature $36.5^{\circ} \mathrm{C}$. The lungs were clear, the heart was rhythmic, $78 \mathrm{bpm}$, and blood pressure was 120/70 mmHg. Except for a tender liver palpated $6 \mathrm{~cm}$ below the costal margin and $16 \mathrm{~cm}$ in epigastrium, physical examination was unremarkable. Her blood group was B, Rh-negative. Erythrocyte count $4,87 \times 10^{6} / \mathrm{mm}^{3}$, haemoglobin 14.3 g/dl, MCV 84.4 fl, MCH 29.3 pg/cell, hematocrit
$41.1 \%$, leukocyte count $8200 / \mathrm{mm}^{3}$ (bands $4 \%$, segmented $71 \%$, eosinophils $3 \%$, lymphocytes $18 \%$, monocytes $4 \%$ ), platelets $260,000 / \mathrm{mm}^{3}$, glucose 100 $\mathrm{mg} / \mathrm{dL}$, urea $19 \mathrm{mg} / \mathrm{dL}$, creatinine $0.9 \mathrm{mg} / \mathrm{dL}$, sodium $136 \mathrm{mEq} / \mathrm{L}$, potassium $4.2 \mathrm{mEq} / \mathrm{L}$, chloride $107 \mathrm{mEq} /$ $\mathrm{L}$, calcium $9 \mathrm{mg} / \mathrm{dL}$, magnesium $1.7 \mathrm{mg} / \mathrm{dL}$, phosphorus $3.9 \mathrm{mg} / \mathrm{dL}$, albumin $3.3 \mathrm{~g} / \mathrm{dL}$, amylase $39 \mathrm{U} /$ $\mathrm{L}$, total bilinubin $0.6 \mathrm{mg} / \mathrm{dL}$, gamma glutamyl transpeptidase $40 \mathrm{U} / \mathrm{L}$, aspartate transaminase $43 \mathrm{U} / \mathrm{L}$, alanine transaminase $21 \mathrm{U} / \mathrm{L}$, alkaline phosphatase $42 \mathrm{U} / \mathrm{L}$, lactic dehydrogenase $744 \mathrm{U} / \mathrm{L}$, prothrombin activity 91.6\%, INR 1.06. Tests for viral hepatitis were unremarkable. Cancer markers showed alpha-fetoprotein $0.96 \mathrm{U} / \mathrm{mL}$, CA 19-9 $1370.50 \mathrm{U} / \mathrm{mL}$, CA 125 59.32, and CEA 25,480 ng/mL

Esophagogastroduodenoscopy was normal. Breast and bone scintigraphy, mammography and breast ultrasound showed no abnormalities. Transvaginal ultrasound showed a left ovarian cyst with apparent septa and solid component (Figure 1C), in addition to low resistance arterial flux 0.49. Colonoscopy disclosed a circumferential ulcerated-vegetating tumour affecting about $80 \%$ of the sigmoid-descending transition lumen (Figure 1D).

Multiple liver metastases in the IV, V, VI, VII and VIII segments of the right lobe, and bilateral ovarian cysts were confirmed at laparotomy. The tumour was involving the entire colon wall (Figu-

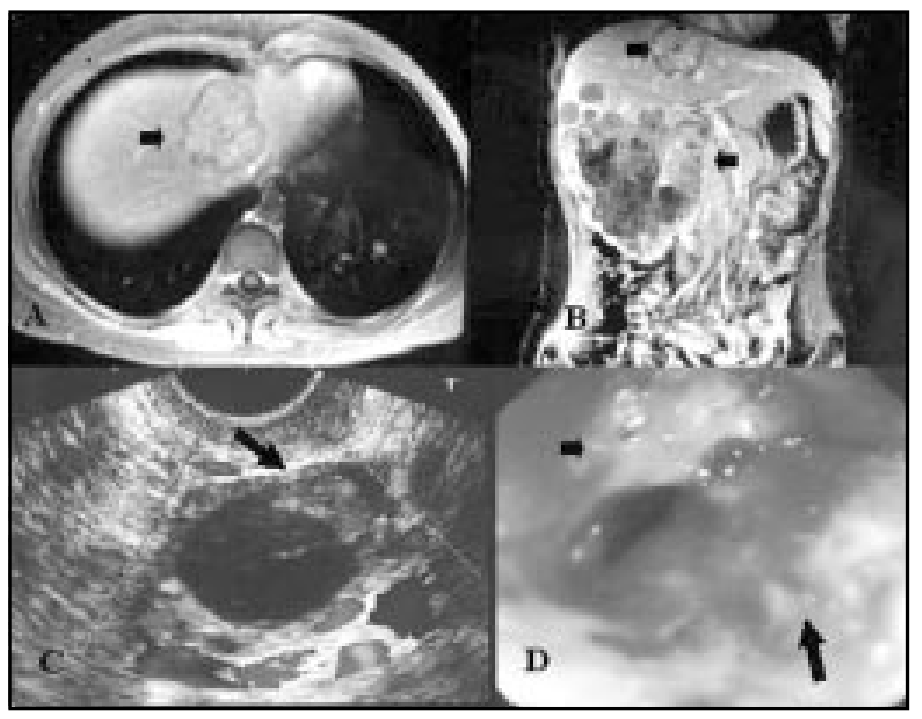

Figure 1. A and B. MRI images of the nodules in the lung base, in addition to large mass and heterogeneous nodules in the liver (arrows). C. Ultrasound images of the left ovarian cyst with a solid component (arrow). D. Colonoscopy image of the tumour, which involves the colon lumen (arrows). 
re $2 \mathrm{~A}$ ) and the surgical procedure consisted of left hemicolectomy and bilateral oophoroplasty.

Liver biopsy samples showed extensive metastatic adenocarcinoma (Figure 2B); and the histopathological features from tumour samples permitted to establish the diagnosis of a stage IV well-differentiated colon adenocarcinoma. The tumour cells showed scanty cytoplasm and large polymorphic nuclei with rare mitoses, and were arranged like glands (Figure 2C). Neoplastic cells were found in blood vessels from colon subserosa and the omentum, and neoplastic infiltration was detected in 8 out of 12 pericolic lymph nodes (Figure 2D). Additionally, there were bilateral benign follicular ovarian cysts and hemomhagic corpus luteum. Tumour cell immunoreactions resulted in: negative cytokeratin 7 (CK 7) and vimentin; positive $(++)$ CK 8 and CK 20; positive (+ focal) CK 1, 5, 10, 11 and 14; and positive (+H) CEA.

Four days after admission, the patient was transfemer to the Oncology Outpatient Section for specialized follow-up and further specific chemotherapy.

\section{DisCUSSION}

This patient came to the hospital because of a recent right hypochondrium pain and the image studies disclosed liver and lung metastases with unsuspected site of origin. Her pelvic ultrasound study was suggestive of an ovarian cystic tumour; however, further investigations revealed a descending colon adenocarcinoma. The tumour resection disclosed tumour cells in local lymph nodes and in the omentum. Worth of note, this patient did not present constitutional or abdominal symptoms. There were no confirmed cases of colon cancer in her family or other cancers related to HNP-CC according to Amsterdam or Bethesda criteria. In spite of the constrictive tumour with $4 \mathrm{~cm}$ diameter and local lymphatic and omentum invasion, she denied gastrointestinal symptoms.

The tumour detection resulted from a search for the origin of widespread metastases disclosed during the preliminary procedures. Initially, a primary ovarian or primary lung cancer could have been considered in this patient. Epithelial ovarian tumours may pose diagnostic challenges in young females with liver metastatic adenocarcinoma, mainly if the pelvic ultrasound images are suggestive of a cystic ovarian tumour. Although primary ovarian cancers can mimic the characteristics of colon cancer as signet-ring cells and surface mucin, ovarian carcinomas are almost all CK7-positive, CK20-negative, and vimentin-positi$\mathrm{ve}^{5}$. With regards to lung cancers, one must clear if they are primary or secondary tumours; furthermore, pathological and morphological features of lung acinar adenocarcinoma may be similar to

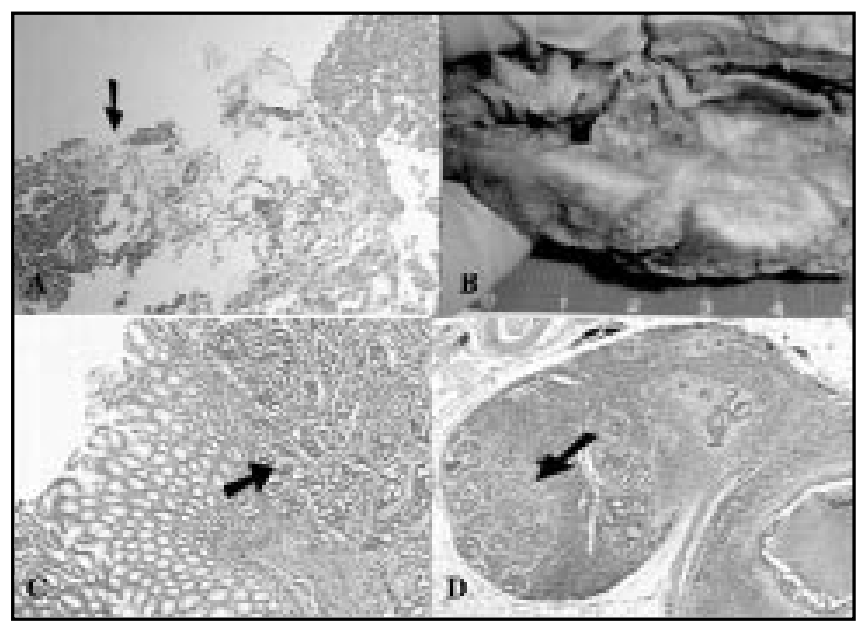

Figure 2. A. Metastases from the adenocarcinoma (arrows) disclosed in the liver biopsy (Hematoxylin-eosin x250). B. Cut surface of gross tumour specimen revealing the constrictive lesion in the colon. C. Well-differentiated colon adenocarcinoma (arrows) infiltrating the wall of the descendent colon (Hematoxylin-eosin x 250). D. Aspect of the pericolic nodal metastases (arrows) from the colon adenocarcinoma (Hematoxylin-eosin x 250). 
those of well-differentiated colon cancer. Although primary lung adenocarcinomas are usually vimentin-negative, they also differ from colon adenocarcinoma because of the CK7-positive and CK20-negative immunostaining ${ }^{6}$.

In a recent description, about $13 \%(96 / 723)$ of patients with colon cancer were $\leq 40$ years old, in near $6 \%(6 / 96)$ of them the tumour was found in the descending colon, and stage III or IV disease and lymph node metastasis occurred in the majority of the cases $^{2}$. A review of 55 articles concerning colorectal cancer showed near $7 \%$ of the tumours affecting people $\leq 40$ years old and $66 \%$ of patients with stage III and IV tumours, data which can explain a lower 5-year survival in this age group ${ }^{3}$. These data are in accordance with a retrospective study including 46/832 (5.5\%) surgical patients with mean age 31.8 years (range 23-39). In that study, nearly $40 \%$ of the patients $(18 / 46)$ were female, $19.5 \%$ of the colorectal cancers were from welldifferentiated type, $70 \%$ of the patients had stage III and IV tumours, and all patients presented conspicuous symptoms indicative of colorectal cancer ${ }^{7}$. Recently, a Brazilian retrospective study including 11 cases of colorectal cancer in people $<40$ years of age found a higher frequency among females (54.5\%), the mean age at diagnosis was 30.5 years,

\section{REFERENCES}

1. Carneiro Neto JD, Barreto JBP, Freitas NS, QueiROZ MA. Câncer colorretal: características clínicas e anatomopatológicas em pacientes com idade inferior a 40 anos. Rev Bras Coloproct 2006; 26: 430-5.

2. Liang $H$, Wang $X N$, Wang BG, Pan $Y$, Lu N, Wang DC, HaO XS. Prognostic factors of young patients with colon cancer after surgery. World J Gastroenterol 2006; 12: 1458-62.

3. O'Connel JB, Maggard MA, Livingston EH, Yo CK. Colorectal cancer in young. Am J Surg 2004; 187 : 343-8. Comments in Am J Surg 2005; 189: 504.

4. Donoso A, Viliarroel L, Pinedo G. Aumento de la mortalidad por cáncer de colon en Chile, 19902003. Rev Méd Chile 2006; 134: 152-8.

5. PRAT J. Ovarian carcinomas, including secondary tumors: diagnostically challenging areas. Mod Pathol 2005; 18: S99-S111.

6. Ikeda S, Fujimore M, Shibata S, Okajima M, IshizakiY, and the average time between the first symptoms and the diagnosis was close to nine months. Contrarily to our finding, there were florid symptoms preceding the diagnosis in the majority of these retrospectively studied cases ${ }^{1}$.

As HPV may infect the colon mucosa ${ }^{8}$ and HPV16 infection has been described in tissues of colorectal cancer ${ }^{9}$, the role of papillomavirus in colon carcinogenesis should be clarified. In the present case, there was no concern about an eventual role of her previous genital HPV infection in the origin of the far advanced colon cancer; furthermore, we could not detect the presence of this virus in the tumour samples.

A delayed diagnosis may explain the advanced stage of cancer in young patients if compared to older groups. Population screening for colorectal cancer could result cost-effective because of the high prevalence, long premalignant course, and favourable change in the course of the disease, followed by early referral and surgical treatment with a clear resection margin ${ }^{10}$.

The target population for bowel cancer screening has been people over 40 years of age. A possible further concern could be the high rate of colorectal cancer mortality registered in younger patients with a late diagnose of widespread cancer.

KURIHARA T ET AL. Combined immunohistochemistry of beta-catenin, cytokeratin 7, and cytokeratin 20 is useful in discriminating primary lung adenocarcinomas from metastatic colorectal cancer. BMC Cancer 2006; 6:31. doi: 10.1186/1471-2407-6-31.

7. Miccin M, Mazzoni G, Cassin D, BetTem E, Colaca L, De Angeus $M$ et al. Il carcinoma colo-rettale nel giovane. Fattori prognostici. G Chir 2005; 26: 365-70.

8. Pérez LO, Abba MC, Laguens RM, Goljow CD. Analysis of adenocarcinoma of the colon and rectum: detection of human papilloma virus (HPV) DNA by polymerase chain reaction. Colorectal Dis 2005; 7: 492-5.

9. Bodaghi S, Yamanegi K, Xiao S-Y, Da Costa M, Palefsky JM, Zheng Z-M. Colorectal Papillomavirus infection in patients with colorectal cancer. Clin Cancer Res 2005; 11: 2862-7.

10. Martínez SR, Young SE, Hoedema RE, Foshag LJ, BILCHIK AJ. Colorectal cancer screening and surveillance: current standards and future trends. Ann Surg Oncol 2006; 13: 768-75. 